\title{
Impact of precipitation and temperature changes on hydrological responses of small-scale catchments in the Ethiopian Highlands
}

\section{Tatenda Lemann, Vincent Roth \& Gete Zeleke}

To cite this article: Tatenda Lemann, Vincent Roth \& Gete Zeleke (2016): Impact of precipitation and temperature changes on hydrological responses of small-scale catchments in the Ethiopian Highlands, Hydrological Sciences Journal, DOI: 10.1080/02626667.2016.1217415

To link to this article: http://dx.doi.org/10.1080/02626667.2016.1217415

Accepted author version posted online: 02

Aug 2016.

Published online: 02 Aug 2016.

Submit your article to this journal $[\pi$

Џll Article views: 9

Q View related articles $ᄃ$

View Crossmark data \lceil 
Publisher: Taylor \& Francis \& IAHS

Journal: Hydrological Sciences Journal

DOI: $10.1080 / 02626667.2016 .1217415$

\section{Impact of precipitation and temperature changes on hydrological responses of small-scale catchments in the Ethiopian Highlands}

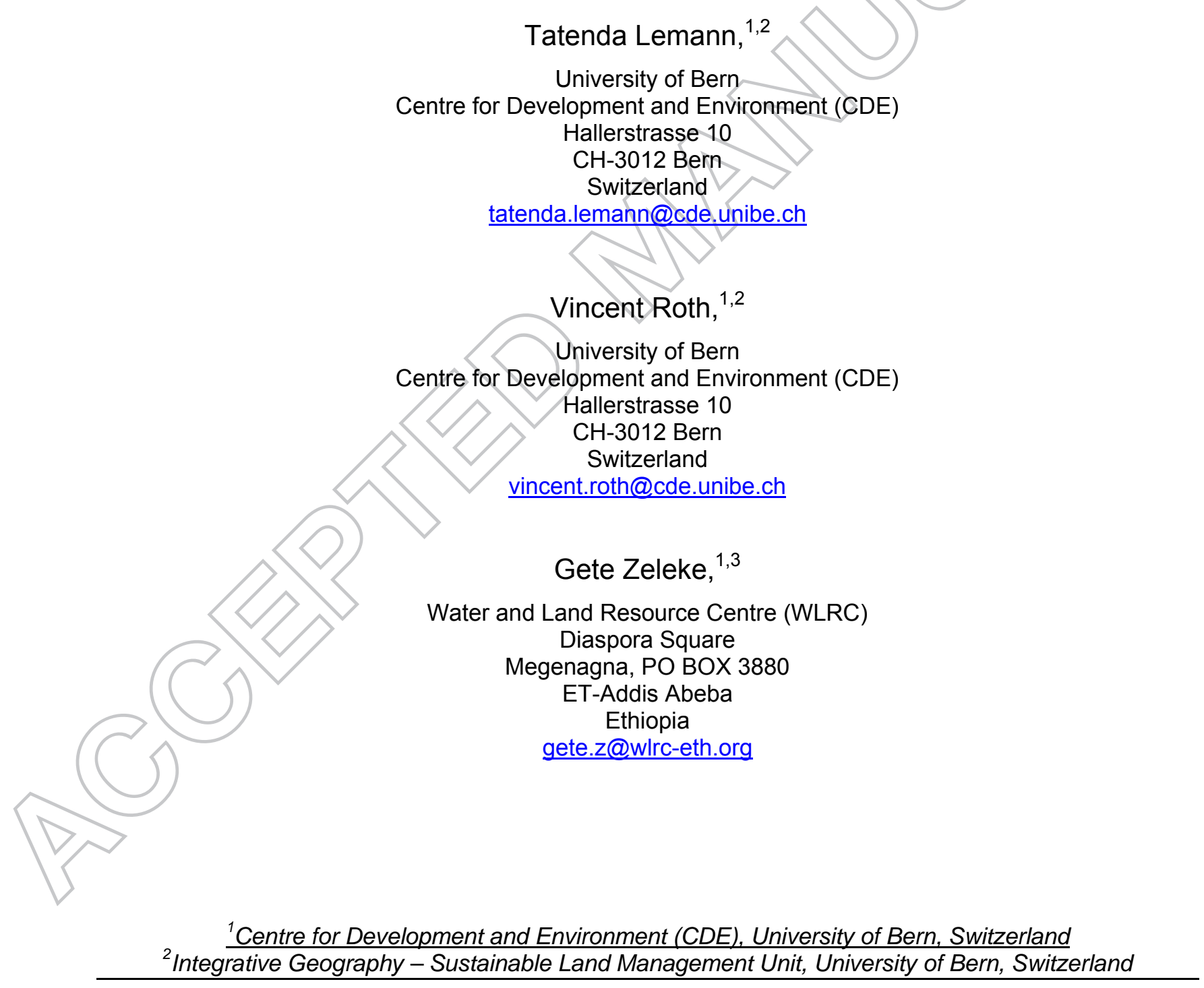




\section{Abstract}

Hydrological response of catchments with different rainfall patterns was assessed to understand the availability of blue and green water and the impacts of changing precipitation and temperature in the Ethiopian Highlands. Monthly discharge of three small-scale catchments was simulated, calibrated, and validated with a dataset of more than 30 years. Different temperature and precipitation scenarios were used to compare the hydrological responses in all three catchments. Results indicate that runoff reacts disproportionately strongly to precipitation and temperature changes: a $24 \%$ increase in precipitation led to a $50 \%$ increase in average annual runoff, and an average annual rainfall-runoff ratio that was $20 \%$ higher. An increase in temperature led to an increase of evapotranspiration and resulted in a decrease in the rainfall-runoff ratio. But a comparison of combined results with different climate change scenarios shows that downstream stakeholders can expect a higher share of available blue water in the future.

Key words: hydrologic cycle; blue and green water; hydrologic modelling; SWAT; SUFI-2; Ethiopian Highlands 


\section{INTRODUCTION}

Until recently, $99 \%$ of agriculture in the highlands of Ethiopia was rain-fed, thus using almost exclusively green water (Hagosa et al. 2011). However, a rapidly growing population and economy have led to an increase in the number and size of dams, as demand for blue water for agricultural and industrial use rises. This development is being observed closely by downstream countries in the Nile Basin, which have limited precipitation and are highly dependent on blue water coming from the Ethiopian Highlands (Hurni et al. 2005).

In the Ethiopian Highlands, the heterogeneity of the seasonal climate, topography, soil, land cover, and land management cause different hydrological responses at catchment and basin level. In other words, the proportion of blue and green water can vary greatly depending on location in the diverse Ethiopian Highlands. These hydrological differences pose one of the main challenges for Ethiopia's water resource management, making it imperative to improve understanding of the impact of the above-mentioned parameters (Taye et al. 2015). To compare and to understand the effects that land use change, soil and water conservation practices, or varying slopes and soils have on an area's hydrological response, hydro-climatic conditions of different locations have to be understood and made comparable. We therefore modelled long-term hydrological responses of three small-scale catchments with different rainfall patterns, and processed scenarios with comparable temperatures and amounts of precipitation.

Many studies have been conducted on the impact of temperature and precipitation on discharge in the Ethiopian Highlands. Most of these studies generated future climate variables with different General Circulation Models (GCMs) such as HadCM3 (Abdo et al. 2009, Dile et al. 2013, Adem et al. 2016), ECHAM5 (Gebre et al. 2015), or several GCMs (Kim and Kaluarachchi 2009, Taye et al. 2011, Koch and Cherie 2013, Melesse et al. 2014). Still, ranges of future precipitation and temperature in these studies last from $-33 \%$ to $+44 \%$, and from $0.95^{\circ} \mathrm{C}$ to $2.56^{\circ} \mathrm{C}$ respectively. Taye et al. (2015) have written a review paper on the implication of climate change on hydrological extremes in the Blue Nile Basin, highlighting that no two research studies in the Blue Nile Basin use a consistent number and type of climate models, emission scenarios, downscaling 
methods, or hydrologic models. Therefore, and because this study focuses on the spatial variation of hydrological responses, we decided against using specific climate change scenarios. Instead we investigated the sensitivity of hydrological response to changes in precipitation and temperature. A comparison of the scenario results with recent climate change studies helps to link the hydrological sensitivities we found with the current debate on climate change.

To model the effects of the differing hydro-climatic conditions on the hydrological response, we used the Soil and Water Assessment Tool (SWAT), a basin-scale, process-based model that operates in daily time steps over longer periods (i.e. years, decades). The SWAT model allows for simultaneous computations on each subwatershed, and it routes the water, sediment, and nutrients from the outlet of the subwatersheds generated by the model to that of the predefined catchment (Gassman et al. 2007). To calibrate and validate the model based on measured discharge, we used the Sequential Uncertainty Fitting program (SUFI-2) (Abbaspour et al. 2004, 2007). Due to their flexibility, SWAT and SUFI-2 have been widely used in different parts of the world and in catchments of different sizes. Schuol et al. (2008b) modelled blue and green water availability on the African continent (30222 $000 \mathrm{~km}^{2}$ ); Betrie et al. (2011), Koch and Cherie (2013), and Ali et al (2014) used SWAT to model sediment management in the Blue Nile Basin (185000 $\mathrm{km}^{2}$ ); and Setegn et al. (2010) modelled sediment yield in the Anjeni catchment $\left(1.1 \mathrm{~km}^{2}\right)$. Many SWAT studies in the Blue Nile Basin have been compared and reviewed by van Griensven et al. (2012). This critical review of the application of SWAT in the upper Nile Basin countries between 2005 and 2011 gives an overview of the different studies conducted, and approaches used.

Other studies explored infiltration rates and saturation-excess runoff in different catchments in the Ethiopian Highlands and beyond (Zeleke 2000, Liu et al. 2008, Steenhuis et al. 2013, Tebebu et al. 2015, Tekleab et al. 2015, Enku et al. 2016). Yet others developed and implemented a simple water-balance model for small-scale catchments (Collick et al. 2009), a saturation-excess erosion model for different scales, (Tilahun 2013a, 2013b) or looked at the ecological (mainly crop type) and topographical (landscape) influence on runoff in the Blue Nile Basin (Bayabil et al. 2010). However, an understanding of the influence of changing precipitation and temperature on the monthly 
and annual blue and green water distribution in catchments with different rainfall patterns is largely lacking. For this study we used a unique 33-year data series (19812013) from the database of the Water and Land Resource Centre (WLRC) in Addis Abeba. These hydrological and meteorological data were collected in three small-scale catchments $\left(1.1 \mathrm{~km}^{2}\right.$ to $\left.4.4 \mathrm{~km}^{2}\right)$ with varying hydro-meteorological characteristics typical of the Ethiopian Highlands. Two of the catchments are situated on the eastern edge of the Upper Blue Nile Basin and characterized by a bimodal rainfall regime, and one is located in the centre of the Blue Nile Basin, with one prolonged rainy season from May to September (Hurni 1998).

This long-term database for the three catchments enabled a detailed model calibration and validation which was essential, in a first step, to create a complete reference discharge time series for each catchment. In a second step, the calibrated and validated model of the three catchments was used to model different precipitation and temperature scenarios, to compare the hydrological response of the different catchments, and to show the influence of changing temperature and precipitation on blue and green water distribution.

\section{MATERIAL AND METHODS}

\subsection{Description of the study area}

The temporal and spatial distribution of rainfall in Ethiopia is largely affected by the movement of air masses associated with the Inter-Tropical Convergence Zone (ITCZ) (Awulachew et al. 2009). During the dry season (November-March), the region is affected by a dry north-eastern continental air mass. From March to May the ITCZ brings rain, particularly to the southern and south-western parts of the basin (Awulachew et al. 2009). In June, the south-western airstream extends over the entire Ethiopian Highlands and produces the major rainy season. The summer months account for a large proportion of mean annual precipitation and this proportion generally increases with latitude (Steenhuis et al. 2009). The three catchments we selected are 
located in the central highlands of Ethiopia within the Blue Nile Basin (Andit Tid and Anjeni) and at its border (Maybar) (Fig. 1).

The Andit Tid catchment is situated in the northern Shewa area, on a volcanic ridge between the central plateau of Ethiopia and the eastern escarpment, in the Wet High Dega agro-ecological zone (Hurni 1998). The climate is characterized by a bimodal rainfall regime (Fig. 2), with average precipitation of more than $1500 \mathrm{~mm} /$ year (19842013). Andit Tid is the largest, highest, and coldest catchment, with an area of $477.3 \mathrm{ha}$, an altitudinal range from 3040 to $3538 \mathrm{~m}$ asl (Bosshart 1997), and average annual minimum and maximum temperatures of $8.2^{\circ} \mathrm{C}$ and $16.4^{\circ} \mathrm{C}$ respectively.

The Maybar catchment is located in the Moist Weyna Dega/Moist Dega agro-ecological zones in the north-eastern part of the central Ethiopian Highlands (Hurni 1998). The average annual minimum and maximum temperatures are $10.9^{\circ} \mathrm{C}$ and $21.7^{\circ} \mathrm{C}$ respectively. Like the Andit Tid catchment, Maybar is characterized by a bimodal rainfall regime (1350 mm/year), with a major rainy season from July to September/October and a minor rainy season from March to May (Fig. 2). Unlike the two other catchments, the Maybar catchment drains into the Awash River to the east of the Ethiopian Highlands. Despite its location just outside the Blue Nile Basin, it is considered typical of the low potential, intensively-cultivated, ox-ploughed cereal belt in the Blue Nile Basin (Bosshart 1999), and its comparable long-term data series is unique in this area.

The Anjeni catchment is located in one of the country's most productive agricultural areas (Liu et al. 2008) - in the Wet Wenya Dega agroecological zone, which has a unimodal rainfall regime with a prolonged rainy season from May to October (Hurni 1998) (Fig. 2). At almost $1700 \mathrm{~mm} /$ year, average annual precipitation is considerably higher than in the Andit Tid and Maybar catchments, and also the changes in temperature are larger and range from $8.6^{\circ} \mathrm{C}$ (average annual minimum temperature) to $23.3^{\circ} \mathrm{C}$ (average annual maximum temperature). The Anjeni catchment is treated with soil and water conservation measures, and due to the deep soil profile the infiltration capacity is higher than in the other catchments (Steenhuis et al. 2013). Table 1 provides a comparative overview of the three catchments. 


\subsection{The Soil and Water Assessment Tool (SWAT)}

SWAT was used to model the spatial and temporal differences of the hydrological response of all three catchments. The model requires information on soils, land use, land management, topography, and climate (Arnold et al. 2012). It is designed to calculate the route runoff, sediments, and contaminants from individual drainage units called Hydrologic Response Units (HRUs), throughout a river basin towards its outlet (Stehr et al. 2009).

SWAT has been widely used in the past. A more detailed description of the model is given in various reviews of its performance and parameterization in Ethiopia and other regions (Schuol and Abbaspour 2007, Stehr et al. 2008, Lin et al. 2010, Setegn et al. 2010, Betrie et al. 2011, Tibebe and Bewket 2011, Mbonimpa 2012, Koch and Cherie 2013, Gessesse et al. 2014).

\subsection{Model input and setup}

\subsubsection{Spatial Data}

The spatial data used in SWAT for the present study included the digital elevation model (DEM), land use data, and soil data. These input data were mainly generated by the WLRC, formerly the Soil Conservation Research Project (SCRP). The DEM, with a spatial resolution of $2 \mathrm{~m}$, was produced from aerial photos by the Centre for Development and Environment (CDE), University of Bern, Switzerland.

The soil map and the physical and chemical soil characteristics were adapted from the SCRP's Research Report 3 (Bono and Seiler 1984) for Andit Tid, and from the SCRP's Soil Conservation Research Report 7 (Weigel 1986) for Maybar. The soil map for Anjeni was adapted from a soil survey carried out by the SCRP (Kejela 1995) and a PhD dissertation by Zeleke (2000).

Land use data were adapted from yearly land ownership maps and land use surveys from WLRC and SCRP, as well as from our own land surveys in 2012. To simulate crop growth and crop yield, we used SWAT's auto-fertilization and auto-irrigation options, and scheduled the growing duration of different crop types by pre-defined heat units. 


\subsubsection{Climate and hydrological data}

Weather input data such as maximum and minimum temperatures, sub-hourly rainfall, and rainfall intensity were compiled from WLRC (2015), available from early 1980 to 2013 (Table 2). All three stations show incomplete time series, as at times the research assistants were unable to collect data, either because of a lack of material or political unrest. In many SWAT studies precipitation data originate from Climate Forecast System Reanalysis (CFSR) of the National Centres for Environmental Prediction (NCEP) (e.g. Brandsma et al. 2013, Fuka et al. 2014). But due to the unsatisfactory accuracy for small-scale catchments in the given climatic conditions (Roth and Lemann, 2015; Dile and Srinivasan, 2014) these data were not used for this study. Instead, we used the actual measured data, using the SWAT weather generator to fill data gaps for precipitation, temperature, solar radiation, relative humidity, and wind speed.

Discharge, required for calibration and validation, was determined by $\operatorname{WLRC}(2015)$, with automatic float gauges combined with manual stage readings. The discharge data series is not complete for reasons mentioned above, missing raw data, or systematic errors such as a bent axis in the limnigraph or a destroyed cross-section.

The potential evaporation data from the Piche evaporimeter or the evaporation pan were not used for calibration and validation due to uncertainties in the survey and data processing. Liu et al. (2008) have already mentioned that potential evaporation measured in the three catchments was too high. For this study, potential evapotranspiration was therefore simulated with the Hargreaves method (Hargreaves et al. 1985),

$$
\lambda E_{0}=0.0023 \cdot H_{0} \cdot\left(T_{\max }-T_{\min }\right)^{0.5} \cdot\left(\bar{T}_{\mathrm{av}}+17.8\right)
$$

where $\lambda$ is the latent heat of vaporization $\left(\frac{\mathrm{MJ}}{\mathrm{kg}}\right), E_{0}$ is the potential evapotranspiration (mm), $H_{0}$ is the extra-terrestrial radiation $\left(\frac{\mathrm{MJ}}{\mathrm{m}^{2}}\right), T_{\max }$ is the maximum temperature $\left({ }^{\circ} \mathrm{C}\right)$, $T_{\text {min }}$ is the minimum temperature, and $\bar{T}_{\mathrm{av}}$ is the mean air temperature.

The actual evapotranspiration was calculated based on the methodology developed by Ritchie (1972). 


\subsubsection{Model setup}

The drainage area in the SWAT Watershed Delineator was selected according to the size and topography of the three catchments between 2 ha (Anjeni and Maybar) and 10 ha (Andit Tid) as the threshold for the delineation of the catchments. This resulted after some manual corrections in 14 sub-basins for Andit Tid, 6 for Maybar, and 10 for Anjeni, with 715,640 , and $776 \mathrm{HRUs}$ respectively. The model was run on a daily time step for 33 years (Maybar), 32 years (Andit Tid), and 30 years (Anjeni), with 2-3 years as a warm-up period. The warm-up period allows the model to establish appropriate initial hydrological conditions (Setegn et al. 2009).

\subsubsection{Sensitivity analysis and calibration setup}

Setegn et al. (2008) compared different calibration algorithms in the Ethiopian Highlands and found the algorithm of SUFI-2 (Abbaspour et al. 2004, 2007) to be an effective method, which allowed adjustment of parameter ranges during calibration with additional iterations. Therefore, SUFI-2 was used in this study for sensitivity analysis, calibration, and validation. Sensitivity analysis was performed to identify the key parameters for the three catchments. In line with the literature, we first chose the parameters most sensitive to discharge (Abbaspour et al. 1997, 2015, White and Chaubey 2005, Setegn et al. 2008, Faramarzi et al. 2009, Betrie et al. 2011, Arnold et al. 2012). We omitted all parameters related to snow (SMTMP.bsn, SFTMP.bsn, SMFMN.bsn, TIMP.bsn), and the measured soil parameters (SOL_AWC, SOL_K, SOL_BD). The flow alpha factor (ALPHA_BF.gw) was calculated with an automated base flow separation and recession analysis technique (Arnold et al. 1995), and not considered in the calibration process. Finally, we used 12 parameters for 3-5 calibration iterations with 500 simulations each. The calibration and validation periods had to be chosen according to the different availability of discharge data at the three stations (Table 2).

To quantify the goodness of the calibration and validation, this study used hydrographic observations and five model evaluation statistics. In addition to the widely used coefficient of determination $\left(R^{2}\right)$ and Nash-Sutcliff efficiency (NSE), we used the $P$ - and $R$-factors and the objective function $b R^{2}$, which we explain below. 
The $P$-factor ranges between 0 and 100 and is the percentage of observed values inside the $95 \%$ prediction uncertainty (95PPU), measured between the $2.5^{\text {th }}$ and $97.5^{\text {th }}$ percentiles of the simulations. The $R$-factor is the thickness of the average 95PPU band divided by the standard deviation of the observed data (Abbaspour 2015). A P-factor of 1 and $R$-factor of 0 is a simulation that exactly corresponds to measured data. In order to compare measured and simulated discharges, this study used the objective function $b R^{2}$ (Abbaspour et al. 2007), a slightly modified version of the efficiency) criterion defined by Krause et al. (2005),

$$
b R^{2}= \begin{cases}|b| R^{2} & \text { if }|b| \leq 1 \\ |b|^{-1} R^{2} & \text { if }|b|>1\end{cases}
$$

where the coefficient of determination $R^{2}$ represents the discharge dynamics, and $b$ is the slope of the regression line between the observed and simulated runoff. The minimum value of the objective function threshold was set to 0.6: according to Faramarzi et al. (2013) and Schuol et al. (2008a), $b R^{2}$ should be $>0.6$ to be sufficient.

According to Arnold et al. (2012) no absolute criteria for judging model performance have been firmly established in the literature, because acceptable statistical measures are project specific (Engel et al. 2007). However, Moriasi et al. (2007) and Andersen et al. (2001) have proposed judging a calibration and validation result as "very good" if $N S E>0.75$ and $R^{2}>0.95$, "good" if $0.65<N S E \leq 0.75$ and $0.85<R^{2} \leq 95$, and "satisfactory" if NSE $>0.5$ and $R^{2}>0.7$. Satisfactory $P$ - and $R$-factors depend on the quality of the measured data. If the measured data are of high quality, then the P-factor should be $>0.8$ and R-Factor < 1 (Abbaspour et al. 2007). But according to Schuol et al. (2008a) a $R$-factor $>0.5$ and $R$-Factor $<1.3$ are still sufficient under less stringent model quality requirements.

\subsubsection{Scenario modelling}

After calibration and validation, the range of parameters with a satisfactory 95PPU, $R^{2}$, $N S E$, and $b R^{2}$ were used to simulate complete reference discharge time series for the three catchments. Because the result is the 95PPU and not a single value, the monthly discharge values are given as a data range. In addition, the best estimated value was 
calculated with the "best parameter" values from the calibration process with SUFI-2. To analyse the impact of temperature and precipitation on the catchment hydrology and the distribution of blue and green water, we performed three simulations with the calibrated model, under different scenario conditions: 1) with higher precipitation in Maybar, the catchment with the lowest measured precipitation rate, to analyse the impact of precipitation on the rainfall-runoff ratio, 2) with higher temperature in Andit Tid, the catchment with the lowest temperatures, to simulate hydrological response with different evapotranspiration rates, and 3) all three catchments with the same average annual precipitation, and minimum and maximum temperatures, to compare blue and green water availability in the different rainfall patterns. These scenario conditions are not linked to a specific climate change scenario, but the results allow a discharge prediction with changing temperature and precipitation values.

The three scenarios were modelled with SUFI-2. Temperature and precipitation of Andit Tid and Maybar were raised and lowered in relative terms to the level of Anjeni. In other words, data were multiplied by one plus a given value, and for the data gaps, the sensitive statistical parameters to generate representative daily climate data were adjusted by the same percentage (see Table 3 ). 


\section{RESULTS AND DISCUSSION}

\subsection{Calibration-uncertainty analysis}

The sensitivity analysis showed that the most sensitive parameters of hydrology were the same for all three catchments; CN2 (SCS runoff curve number), CH_K (Effective hydraulic conductivity in main channel alluvium), and $\mathrm{CH} \_\mathrm{N}$ (Manning's " $n$ " value for the main channel). But the sensitivity of the different parameters varied between each iteration and between the different catchments. Consequently, all 12 selected parameters were used for calibration and validation for all three catchments. The parameter's ranges were reduced after each iteration until the calibration result was satisfactory (see Table 4).

The overall goodness-of-fit for calibration was good for all three catchments, although there were slight differences regarding the five model evaluation statistics. The relative width of the 95PPU was less than 1 (P-factor $<1$ ) for all three catchments and the 95PPU enclosed more than $80 \%$ of the measured data $(P$-factor $>0.80)$ for Andit Tid and Anjeni. Only Maybar had a slightly smaller P-factor of 0.75 , but according to Schuol et al. (2008a) this is still sufficient. The NSE and $R^{2}$ were "good" to "very good" for all three catchments (Table 5),

The lower $P$-factor, and NSE and $R^{2}$ values in Maybar may be a result of periodically overestimated discharge during the minor rainy season. Upon checking the measured discharge data, we found that in some months "no discharge" was measured or written down. One reason for "no discharge" may be water supply for agricultural or residential use, which was not taken into account in this study, or a very high infiltration rate of the dry soils, which could not be modelled with SWAT; another may be that discharge was not consistently measured outside the major rainy season. The comparison of the rainfall-runoff ratios in the minor rainy season showed that periods with "no discharge" did not correlate with rainfall amount and rainfall intensity, and mainly occur randomly and not only during dry periods. Because there are no irrigation activities when it is raining, irrigation cannot be the only reason for "no discharge" values. Therefore, and because of the random appearance of "no discharge", the simulated discharge values 
are more plausible than the measured data with "no discharge". According to Tilahun et al. (2013a) it is also likely that a part of the subsurface water passes under the gauging station and cannot be measured at the outlet of the watershed, leading to overestimated simulated discharge. But the eventuality of deep percolation has been included in the simulations with the ranges of the parameters used for calibration (Table 4) such as RCHRG_DP (deep aquifer percolation fraction), GWQMN (threshold depth of water in the shallow aquifer required for return flow to occur), or GW_REVAP (Groundwater "revap" coefficient). Even with "good" statistical calibration results the simulation underestimated some of the discharge peaks in August and especially the highest discharge peaks in the Andit Tid catchment (Fig. 3). Figure 4 shows that the measured monthly rainfall-runoff ratios from June-August are mostly higher than the upper 95PPU. One reason might be high rainfall erosivity in certain years (Bosshart 1999) and the resulting above-average discharge level, which were not reproduced with SWAT. According to the measured data, more than $90 \%$ of precipitation left the Andit Tid catchment as blue water in 1985 while less than $30 \%$ did so in 1987 , when most of the precipitation left the catchment through evapotranspiration or lateral flow. Another reason for the underestimated discharge in Andit Tid might be erroneous data or unmonitored rainstorms, as it seems unlikely there would be more discharge than rainfall in August, the month with the highest rainfall amount. In a catchment the size and altitude of Andit Tid, temporal and spatial variability in precipitation can be expected and heavy rainfall in the upper part can generate high runoff without being measured. As a result of these simulation or data problems, simulated discharge peaks in years with high precipitation amounts and erosivity can underestimate the true water level.

Based on the available measured discharge data, the length of the validation period was different for all three catchments (see Table 2 and Fig. 3). In Maybar and Anjeni $R^{2}$ and NSE showed "good" to "very good" results for the validation period. Andit Tid had slightly lower statistical measures due to a deviation between the measured and the simulated monthly discharge values in 1995 and 1996. The deviation may be caused by incorrect measured precipitation (too low), which had a strong influence on the validation statistics due to the short validation period. The $P$ - and $R$-factors were "sufficient" for all three catchments. 
For the hydrographic observations and model evaluation statistics, calibration and validation based on river discharge were "good" to "very good" for all three catchments. Consequently, the calibrated parameter band was used to simulate missing discharge data and to process three scenarios with comparable temperatures and amounts of precipitation.

\subsection{Quantification of the rainfall-runoff ratio}

With the calibrated parameter band, we simulated the 95PPU ranges for missing monthly discharge values. To simulate monthly values, we used the "best parameter" settings from the calibration process in SUFI-2 in addition to the 95PPU band. Being aware of the uncertainty and randomness, as it could easily change if slightly different intervals for the parameters are used; the "best simulation value" was used as a best approximation to the measured value.

In the case of Andit Tid, with no reliable discharge data after 1997, simulated discharge could not be verified with current data; therefore, we cannot exclude changes in certain parameters in the last 15 years. Extreme annual rainfall-runoff ratios like 1985 (> 90\%) or $1987(<30 \%)$ were not simulated after 1997, even if there were large annual precipitation and discharge fluctuations (Fig. 4). In Anjeni and Maybar, where data of the last few years were used for validation, the recent situation was considered in the calibration-validation process and large long-term parameter changes can be precluded.

The measured and newly modelled discharge and precipitation data from Andit Tid, Maybar, and Anjeni revealed significant differences in the hydrological responses of each catchment (Fig. 4). In all three stations annual precipitation and discharge increased over the last three decades, but not in parallel: each catchment showed a tendency towards increased annual rainfall-runoff ratios at very different levels. Over the last 30 years, the simulated average rainfall-runoff ratio (best simulation) is roughly 0.62 in Andit Tid, 0.46 in Anjeni, and 0.38 in Maybar (see Table 6). However, there are some deviations between the measured and the simulated average rainfall-runoff ratios. These resulted from incomplete measured discharge time series and slight 
differences between the measured and the "best simulated" discharge. The measured average annual rainfall-runoff ratios for Andit Tid, Maybar, and Anjeni for the years with measured precipitation and discharge data are $0.59,0.29$, and 0.46 respectively (Table 1).

Hurni et al. (2005) measured the hydrological responses of test plots with different land use types in these small-scale catchments and also found high variability in the runoff coefficient, with the highest rainfall-runoff ratio on a cultivated plot in Anjeni. One reason for these diverse hydrological responses may be the different rainfall patterns (precipitation) and altitude (temperature) of the three stations. As is clear from Fig. 4 the rainfall-runoff ratio changes as the wet season progresses to a higher rainfall-runoff ratio later in the major rainy season. This is in line with Enku et al. (2016), who showed in the Anjeni catchment that discharge relies on the watershed storage threshold and that the rainfall-runoff ratio increases after the watershed storage threshold is reached.

As Liu et al. (2008) and Steenhuis et al. (2013) proposed, each catchment reaches an approximate threshold of $500 \mathrm{~mm}$ of effective cumulative precipitation since the start of the rainy season, where hydrological response can be predicted by its linear relationship with precipitation. Liu et al. (2008) and Steenhuis et al. (2013) were looking at the rainfall-runoff ratio after the sum of effective precipitation exceeded $500 \mathrm{~mm}$; they found a rainfall-runoff ratio for Andit Tid and Anjeni (0.56 and 0.50$)$ which was similar to what we simulated in this study for the whole year (see Table 6), but they found a higher rainfall-runoff ratio for Maybar (0.48). This difference can be explained by the smaller amount of precipitation in Maybar, where the $500 \mathrm{~mm}$ threshold has a higher impact on the annual rainfall-runoff ratio. Over the last 30 years, Anjeni (one prolonged rainy season) received $24 \%$ more precipitation per year than Maybar (two rainy seasons). This shows that the Maybar catchment might not reach the aforementioned threshold point at all, or only later in the major rainy season, while the Anjeni catchment reached the threshold earlier due to heavier rainfall concentrated in a single rainy season. Consequently, more precipitation reaches the river in Anjeni due to higher annual precipitation rates and saturation-excess processes, while in Maybar proportionally more precipitation infiltrates into the soil due to less precipitation and two 
rainy seasons. To see the impact of precipitation on the rainfall-runoff ratio, we modelled scenario 1, where Maybar's precipitation was raised to the level of Anjeni.

Over the last 30 years, the Andit Tid catchment, with the highest rainfall-runoff ratio, had on average 10\% less precipitation than Anjeni and 19\% more than Maybar. Possible explanations for the high rainfall-runoff ratio, proposed by Liu et al. (2008), are the steep slopes, soil with a lower infiltration capacity, and partly, poor soil and water conservation measures (these were better preserved in Anjeni and Maybar). Another reason may be the high altitude of Andit Tid with lower temperatures and thus lower evapotranspiration rates. The annual maximum and minimum temperatures in Andit Tid were on average $6.8^{\circ} \mathrm{C}$ and $0.38^{\circ} \mathrm{C}$ lower than in Anjeni. These temperature differences were one of the main reasons for the $25 \%$ lower potential evapotranspiration in Andit Tid than in Anjeni (Table 6). Higher potential evapotranspiration implies a greater requirement for available water stored in the soil to satisfy vegetation needs (Pascual et al. 2014) and a higher evaporation rate of surface water. In short, higher temperatures increase the green water content and decrease discharge. To show the effects of the different temperatures, in scenario 2 we increased the temperature of Andit Tid to the level of Anjeni and compared the rainfall-runoff ratios.

To compare the rainfall-runoff ratios of the three catchments under the same meteorological conditions, we modelled scenario 3, where we brought all three catchments to the average annual precipitation and temperature of Anjeni.

\subsection{Hydrological responses with different scenarios}

\subsubsection{Scenario 1 (Precipitation)}

To see the impact of precipitation on the rainfall-runoff ratio, we modelled scenario 1 , where precipitation of Maybar was raised $+24 \%$, to the level of Anjeni. In scenario 1 the average annual discharge in Maybar increased disproportionately to precipitation and was more than $50 \%$ higher than that simulated with measured precipitation data. As a result, the 95PPU of the average annual rainfall-runoff ratio was approximately $20 \%$ higher in scenario 1 and thus similar to the average annual rainfall-runoff ratio in Anjeni 
with the same precipitation rate (see Fig. 5). This result indicates that the hydrological response in Anjeni and Maybar are similar with the same amount of annual precipitation, even if the two stations have different rainfall patterns. This can be explained with saturation-excess processes, and similar threshold points, where hydrological response can be predicted by a linear relationship with precipitation (Liu et) al. 2008, Steenhuis et al. 2013). In scenario 1 the above-mentioned threshold point in Maybar was reached earlier, and due to saturation-excess processes, a higher percentage of precipitation was drained through the river. Liu et al. (2008) and Steenhuis et al. (2013) who were only looking at the rainfall-runoff ratio after the 500 $\mathrm{mm}$ precipitation threshold was reached, even found a slightly higher rainfall-runoff ratio for Maybar with 0.5 (Anjeni 0.48).

The scenario shows that increasing amounts of precipitation, observed in the three observatories over the last 33 years, will increase the share of blue water leaving the Ethiopian Highlands. This tendency was also described in many climate change scenarios, where annual precipitation is increasing up to $+44 \%$ (Kim and Kaluarachchi 2009, Dile et al. 2013, Gebre et al. 2015, Adem et al. 2016).

\subsubsection{Scenario 2 (Temperature)}

The potential evapotranspiration in Andit Tid rose in scenario 2 from $1099 \mathrm{~mm} / \mathrm{year}$ to $1608 \mathrm{~mm} /$ year (Fig. 6) and is close to the potential evapotranspiration in Anjeni (1505 $\mathrm{mm} / \mathrm{year}$ ) with the same average minimum and maximum temperatures. The difference of $100 \mathrm{~mm} / \mathrm{year}$ can be explained by the greater diurnal temperature variation in Anjeni and the Hargreaves method we used (see equation 1), which takes into account the difference between the maximum and the minimum temperatures (Hargreaves et al. 1985). The higher temperature in Andit Tid resulted in a decrease in the rainfall-runoff ratio of almost $10 \%$ (Table 6 ). The decrease can also be explained by the effective precipitation threshold (precipitation minus potential evaporation) of $500 \mathrm{~mm}$ which will be reached later in the rainy season due to higher potential evaporation (Liu et al. 2008, Steenhuis et al. 2013)

In other words, increasing temperature, as predicted by the climate change scenarios generated with different GMCs (up to $+2.56^{\circ} \mathrm{C}$ ) (Abdo et al. 2009, Kim and Kaluarachchi 
2009, Mengistu and Sorteberg 2011, Taye et al. 2011, Dile et al. 2013, Gebre et al. 2015, Adem et al. 2016), reduces the proportion of blue water leaving the catchment (Taye et al. 2015). While this water is missing for irrigation in downstream countries, more green water is available for upstream stakeholders. With an adapted water management approach proposed by Rockström (2003), increasing non-productive evaporation can be shifted to productive transpiration and improve crop yield in the headwaters.

\subsubsection{Scenario 3 (Precipitation \& Temperature)}

In scenario 3, average annual precipitation and minimum and maximum temperatures were raised and lowered to a common level - that of Anjeni - for all three catchments (Table 6). Looking at the 95PPU band the rainfall-runoff ratio in Andit Tid was 5\% higher in scenario 3 than in scenario 2, but decreased by almost $5 \%$ compared to the simulation with measured precipitation and temperature. Due to higher temperatures in scenario 3 , the $10 \%$ higher precipitation rate did not lead to an increase in the rainfall-runoff ratio (Fig. 7).

In Maybar, where the rainfall-runoff ratio was $10 \%$ higher in scenario 3, the increase was smaller than in scenario 1 The reason is the higher potential evapotranspiration rate, caused by a higher average annual temperature and a greater average diurnal temperature variation (see equation 1), which was not considered in scenario 1. Overall, in scenario 3 the hydrological responses of all three catchments are more similar to each other than the hydrological responses calculated with the measured precipitation and the simulated reference discharge of the different catchments (Table 6).

Due to percentage changes of the measured data in scenario 3 , the rainfall pattern and daily temperature fluctuations were still different in each catchment. Therefore, the intensity as well as spatial and temporal distribution of precipitation in and between the three catchments is still considerable and should not be neglected. For example, Andit Tid, being more than four times as big as the two other catchments, had a greater risk of unmonitored rainstorms and therefore displayed a wider range of possible runoff responses than the two smaller catchments (Liu et al. 2008). 
Despite these uncertainties, the changes in the rainfall-runoff ratio between the scenarios proved the influence of precipitation and temperature on the hydrological response. The differences between the three catchments in scenario 3, with the same temperature and precipitation, showed the influence of other parameters which were not used for scenario modelling. So "steep" slopes, like in Andit Tid and Maybar (average slope: > 29\%), and soils with a low infiltration capacity, like in Andit Tid (Liu et al. 2008), generate more runoff than "gentle" slopes and deep soils, like in Anjeni (average slope: $19 \%$ ). Differences in the hydrological responses between Andit Tid and Maybar, with the same rainfall pattern, average slope, and growing season, can in addition be explained by parameters which are directly influenced by humans, such as a higher standard of soil and water conservation measures in Maybar (Hurni et al. 2005, Liu et al. 2008).

Future hydrological responses will be highly dependent on the amplitude of the change of precipitation and temperature. Both parameters have to be taken into account to assess future blue and green water resources. Already small increases in precipitation can lead to a disproportionately higher rainfall-runoff ratio, but increasing temperature will convert blue to green water and decrease the amount of blue water for downstream stakeholders, even if future temperature scenarios do not reach the amplitude of scenario 2 and scenario 3 . 


\section{SUMMARY AND CONCLUSION}

In this study, we calculated the long-term hydrological responses of three small-scale catchments with different hydrological and meteorological conditions. To do so, we used the process-based semi-distributed hydrological model SWAT, carrying out calibration and validation against measured discharge as well as sensitivity analysis, to simulate in a first step a complete reference discharge time series for the three catchments. To characterize the model's uncertainty, we used SUFI-2 to generate a 95PRU band In a second step, we generated three scenarios, where we adapted the different temperature and precipitation values of the three study regions to a common level. This allowed us to compare hydrological responses of the three catchments under similar meteorological conditions. Results show that increasing precipitation generates a disproportionate increase of discharge and therefore a higher rainfall-runoff ratio, while increasing temperature reduces the share of blue water for downstream countries.

These results indicated that differences in rainfall-runoff ratio and blue and green water availability in catchments with different rainfall patterns are largely caused by climatological parameters, such as precipitation and temperature. With the common denominator (temperature and precipitation) we established a basis to compare the effects of other parameters, such as land use change as well as soil and water conservation practices. At the same time, a comparison of the scenarios we used and different climate change scenarios showed that the impact of climate change on blue and green water distribution depends on the combination of precipitation and temperature change. Considering both parameters, many climate change scenarios will lead to a higher share of blue water for downstream stakeholders, but also to more green water in the headwaters, which can increase crop yield, when non-productive evaporation is shifted to productive transpiration.

This study contributes to the as of yet scant body of knowledge on distribution and availability of blue and green water in small-scale catchments with different rainfall patterns. This knowledge is essential for assessing and improving watershed management strategies for the long-term planning of local, national, and international water, energy, and food security. 


\section{Acknowledgments}

This research was supported by the Centre for Development and Environment (CDE), and the Institute of Geography, University of Bern, Switzerland. We are grateful to the Water and Land Resource Centre (WLRC), Addis Abeba, Ethiopia, for providing data, and to Tina Hirschbuehl for editing.

\section{Literature}

Abbaspour, K.C., 2015. SWAT-CUP 2012: SWAT calibration and uncertainty programs - A user manual. Eawag: Swiss Federal Institute of Aquatic Science and Technology.

Abbaspour, K.C., van Genuchten, M.T., Schulin, R., and Schläppi, E., 1997. A sequential uncertainty domain inverse procedure for estimating subsurface flow and transport parameters. Water Resources Research, 33 (8), 1879-1892.

Abbaspour, K.C., Johnson, C.A., and van Genuchten, M.T., 2004. Estimating uncertain flow and transport parameters using a sequential uncertainty fitting procedure. Vadose Zone Journal, 3 (4), 13401352.

Abbaspour, K.C., Rouholahnejad, E., Vaghefi, S., Srinivasan, R., Yang, H., and Kløve, B., 2015. A Continental-Scale Hydrology and Water Quality Model for Europe: Calibration and uncertainty of a high-resolution large-scale SWAT model. Journal of Hydrology.

Abbaspour, K.C., Yang, J., Maximov, I., Siber, R., Bogner, K., Mieleitner, J., Zobrist, J., and Srinivasan, R., 2007. Modelling hydrology and water quality in the pre-alpine/alpine Thur watershed using SWAT. Journal of Hydrology, 333 (2-4), 413-430.

Abdo, K.S., Fiseha, B.M., Rientjes, T.H.M., Gieske, A.S.M., and Haile, A.T., 2009. Assessment of climate change impacts on the hydrology of Gilgel Abay catchment in Lake Tana Basin, Ethiopia. Hydrological Processes, 23, 3661-3669.

Adem, A.A., Tilahun, S.A., Ayana, E.K., Worqlul, A.W., Assefa, T.T., Dessu, S.B., and Melesse, A.M., 2016. Climate Change Impact on Stream Flow in the Upper Gilgel Abay Catchment, Blue Nile basin, Ethiopia. In: A.M. Melesse and W. Abtew, eds. Landscape Dynamics, Soils and Hydrological Processes in Varied Climates. Springer International Publishing, 645-673.

Ali, Y.S.A., Crosato, A., Mohamed, Y.A., Abdalla, S.H., and Wright, N.G., 2014. Sediment balances in the Blue Nile River Basin. International Journal of Sediment Research, 29 (3), 316-328.

Andersen, J., Refsgaard, J.C., and Jensen, K.H., 2001. Distributed hydrological modelling of the Senegal River Basin - model construction and validation. Journal of Hydrology, 247 (3-4), 200-214.

Arnold, J.G., Allen, P.M., Muttiah, R., and Bernhardt, G., 1995. Automated Base Flow Separation and Recession Analysis Techniques. Ground Water, 33 (6), 1010-1018.

Arnold, J.G., Moriasi, D.N., Gassman, P.W., Abbaspour, K.C., White, M.J., Srinivasan, R., Santhi, C., Harmel, R.D., van Griensven, A., Van Liew, M.W., Kannan, N., and Jha, M.K., 2012. SWAT: Model use, calibration, and validation. Transactions of the ASABE, 55(4), 1491-1508.

Awulachew, S.B., McCartney, M., Steenhuis, T.S., and Ahmed, A.A., 2009. A review of hydrology, 
sediment and water resource use in the Blue Nile Basin. Working Paper 131. International Water Management Institute (IMWI).

Bayabil, H.K., Tilahun, S.A., Collick, A.S., Yitaferu, B., and Steenhuis, T.S., 2010. Are runoff processes ecologically or topographically driven in the (sub) humid Ethiopian highlands? The case of the Maybar watershed. Ecohydrology, 3 (4), 457-466.

Betrie, G.D., Mohamed, Y.A., van Griensven, A., and Srinivasan, R., 2011. Sediment management modelling in the Blue Nile Basin using SWAT model. Hydrology and Earth System Sciences, 15 (3), 807-818.

Bono, R. and Seiler, W., 1984. The Soils of the Andit-Tid Research Unit (Ethiopia) Classification, Morphology and Ecology, with soil map 1:10'000. University of Bern, Switzerland.

Bosshart, U., 1997. Catchment discharge and suspended sediment transport as indicators of physical soil and water conservation in the Michet catchment, Anjeni Research Unit. A case study in the northwestern Highlands of Ethiopia. University of Berne, Switzerland.

Bosshart, U., 1999. Hydro-sedimentological characterisation of Kori Sheleko and Hulet Wenz Catchments, Maybar and Andit Tid research units: Case studies of two SCRP micro-catchments in the northeastern highlands of Ethiopia. University of Berne, Switzerland.

Brandsma, J., van den Eertwegh, G.A.P., Droogers, P., Bai, Z., and Zhang, S., 2013. Green and Blue Water $R$ esources and Management Scenarios using the SWAT model for the Upper Duhe Basin, ChinaFeasibility Study. Report FutureWater 126. Wageningen, Netherlands.

Collick, A.S., Easton, Z.M., Ashagrie, T., Biruk, B., Tilahun, S., Adgo, E., Awulachew, S.B., Zeleke, G., and Steenhuis, T.S., 2009. A simple semi-distributed water balance model for the Ethiopian highlands. Hydrological Processes, 23 (26), 3718-3727.

Dile, Y.T., Berndtsson, R., and Setegn, S.G., 2013. Hydrological Response to Climate Change for Gilgel Abay River, in the Lake Tana Basin - Upper Blue Nile Basin of Ethiopia. PloS one, 8 (10), e79296.

Dile, Y.T. and Srinivasan, R., 2014. Evaluation of CFSR climate data for hydrologic prediction in datascarce watersheds: an application in the Blue Nile River Basin. Journal of the American Water Resources Association, 50 (5), 1226-1241.

Engel, B., Storm, D., White, M., Arnold, S.G., and Arabi, M., 2007. A Hydrologic/Water Quality Model Application Protocol. Journal of the American Water Resources Association, 43 (5), 1223-1236.

Enku, T., Melesse, A.M. Ayana, E.K., Tilahun, S.A., Zeleke, G., and Steenhuis, T.S., 2016. Watershed Storage Dynamics in the Upper Blue Nile Basin: The Anjeni Experimental Watershed, Ethiopia. In: A.M. Melesse and W. Abtew, eds. Landscape Dynamics, Soils and Hydrological Processes in Varied Climates. Springer/nternational Publishing, 261-277.

Faramarzi, M., Abbaspour, K.C., Ashraf Vaghefi, S., Farzaneh, M.R., Zehnder, A.J.B., Srinivasan, R., and Yang, H., 2013. Modeling impacts of climate change on freshwater availability in Africa. Journal of Hydrology, 480, 85-101.

Faramarzi, M., Abbaspour, K.C., Schulin, R., and Yang, H., 2009. Modelling blue and green water resources availability in Iran. Hydrological Processes, 23 (3), 486-501.

Fuka, D.R., Walter, M.T., MacAlister, C., Degaetano, A.T., Steenhuis, T.S., and Easton, Z.M., 2014. Using the Climate Forecast System Reanalysis as weather input data for watershed models. Hydrological Processes, 28 (22), 5613-5623.

Gassman, P.W., Reyes, M.R., Green, C.H., and Arnold, 2007. The Soil and Water Assessment Tool: Historical development, applications, and future research directions. Center for Agricultural and Rural Development, lowa State University, lowa.

Gebre, S.L., Tadele, K., and Mariam, B.G., 2015. Potential Impacts of Climate Change on the Hydrology 
and Water resources Availability of Didessa Catchment, Blue Nile River Basin, Ethiopia. Journal of Geology \& Geosciences, 4 (1), 193.

Gessesse, B., Bewket, W., and Bräuning, A., 2014. Model-based characterization and monitoring of runoff and soil erosion in response to land use/land cover changes in the Modjo watershed, Ethiopia. Land Degradation \& Development.

van Griensven, A., Ndomba, P., Yalew, S., and Kilonzo, F., 2012. Critical review of the application of SWAT in the upper Nile Basin countries. Hydrology and Earth System Sciences Discussions, 9 (3), 3761-3788.

Hagosa, F., Makombe, G., Namara, R., and Awulachew, S., 2011. Importance of Irrigated Agriculture to the Ethiopian Economy: Capturing the direct net benefits of irrigation. Ethiopian Journal of Development Research, 32 (1), 1-37.

Hargreaves, G.L., Hargreaves, G.H., and Riley, J.P., 1985. Agricultural Benefits for Senegal River Basin. Journal of Irrigation and Drainage Engineering, 111 (2), 113-124.

Hurni, H., 1998. Agroecological Belts of Ethiopia Explanatory notes on three maps at a scale of 1:1,000,00. Soil Conservation Research Programme, Research Report 43. Bern, Switzerland: Centre for Development and Environment (CDE).

Hurni, H., Tato, K., and Zeleke, G., 2005. The Implications of Changes in Population, Land Use, and Land Management for Surface Runoff in the Upper Nile Basin Area of Ethiopia. Mountain Research and Development, 25 (2), 147-154.

Kejela, K., 1995. The soils of the Anjeni Area - Gojam Research Unit, Ethiopia. University of Bern, Switzerland.

Kim, U. and Kaluarachchi, J.J., 2009. Climate Change Impacts on Water Resources in the Upper Blue Nile River Basin, Ethiopia. Journal of the American Water Resources Association, 45 (6), 1361-1378.

Koch, M. and Cherie, N., 2013. SWAT-Modeling of the Impact of future Climate Change on the Hydrology and the Water Resources in the Upper Blue Nile River Basin, Ethiopia. Proceedings of the 6th International Conference on Water Resources and Environment Research, ICWRER, 6 (6), 488-523.

Krause, P., Boyle, D.P., and Bäse, F., 2005. Comparison of different efficiency criteria for hydrological model assessment. Advances in Geosciences, 5 (5), 89-97.

Lin, S., Jing, C., Chaplot, V., Yu, X., Zhang, Z., Moore, N., and Wu, J., 2010. Effect of DEM resolution on SWAT outputs of runoff, sediment and nutrients. Hydrology and Earth System Sciences Discussions, 7 (4), 4411-4435.

Liu, B.M., Collick, A.S., Zeleke, G., Adgo, E., Easton, Z.M., and Steenhuis, T.S., 2008. Rainfall-discharge relationships for a monsoonal climate in the Ethiopian highlands. Hydrological Processes, 22 (7), 1059-1067.

Mbonimpa, E.G., 2012. SWAT Model Application to Assess the Impact of Intensive Corn-farming on Runoff, Sediments and Phosphorous loss from an Agricultural Watershed in Wisconsin. Journal of Water Resource and Protection, 04 (07), 423-431.

Melesse, A., Abtew, W., and Setegn, S.G., 2014. Nile River Basin: Ecohydrological Challenges, Climate Change and Hydropolitics. Springer Science \& Business Media.

Mengistu, D.T. and Sorteberg, A., 2011. Validation of SWAT simulated streamflow in the Eastern Nile and sensitivity to climate change. Hydrology and Earth System Sciences Discussions, 8 (5), 90059062.

Moriasi, D.N., Arnold, J.G., Van Liew, M.W., Bingner, R.L., Harmel, R.D., and Veith, T.L., 2007. Model evaluation guidelines for systematic quantification of accuracy in watershed simulations. Trans. ASABE, 50 (3), 885-900. 
Pascual, D., Pla, E., Lopez-Bustins, J.A., Retana, J., and Terradas, J., 2014. Impacts of climate change on water resources in the Mediterranean Basin: a case study in Catalonia, Spain. Hydrological Sciences Journal, 141217125340005.

Ritchie, J.T., 1972. Model for predicting evaporation from a row crop with incomplete cover. Water Resources Research, 8 (5), 1204-1213.

Rockström, J., 2003. Water for food and nature in drought-prone tropics: vapour shift in rain-fed agriculture. Philosophical transactions of the Royal Society of London. Series B, Biological sciences, 358 (1440), 1997-2009.

Roth, V. and Lemann, T., 2016. Comparing CFSR and conventional weather data for discharge and soil loss modelling with SWAT in small catchments in the Ethiopian Highlands. Hydrology and Earth System Sciences, 20 (2), 921-934.

Schuol, J. and Abbaspour, K.C., 2007. Using monthly weather statistics to generate daily data in a SWAT model application to West Africa. Ecological Modelling, 201 (3-4), 301-311.

Schuol, J., Abbaspour, K.C., Srinivasan, R., and Yang, H., 2008a. Estimation of freshwater availability in the West African sub-continent using the SWAT hydrologic model. Journal of Hydrology, 352 (1-2), 30-49.

Schuol, J., Abbaspour, K.C., Yang, H., Srinivasan, R., and Zehnder, A.J.B., 2008b. Modeling blue and green water availability in Africa. Water Resources Research, 44 (7).

Setegn, S.G., Dargahi, B., Srinivasan, R., and Melesse, A.M., 2010. Modeling of Sediment Yield From Anjeni-Gauged Watershed, Ethiopia Using SWAT Model. Journal of the American Water Resources Association, 46 (3), 514-526.

Setegn, S.G., Srinivasan, R., and Dargahi, B., 2008. Hydrological Modelling in the Lake Tana Basin, Ethiopia Using SWAT Model. The Open Hydrology Journal, 2 (1).

Setegn, S.G., Srinivasan, R., Dargahi, B., and Melesse, A.M., 2009. Spatial delineation of soil erosion vulnerability in the Lake Tana Basin, Ethiopia. Hydrological Processes, 24 (3), 357-367.

Steenhuis, T.S., Collick, A.S., Easton, Z.M., Leggesse, E.S., Bayabil, H.K., White, E.D., Awulachew, S.B., Adgo, E., and Ahmed, A.A., 2009. Predicting discharge and sediment for the Abay (Blue Nile) with a simple model. HYDROLOGICALPROCESSES, 23 (26), 3728-3737.

Steenhuis, T.S., Hrnčír, M., Poteau, D., Romero Luna, E.J., Tilahun, S.A., Caballero, L.A., Guzman, C.D., Stoof, C.R., Šanda, M., Yitaferu, B., and Císlerová, M., 2013. A Saturated Excess Runoff Pedotransfer Function for Vegetated Watersheds. Vadose Zone Journal, 12 (4).

Stehr, A., Debels, P., Arumi, J.L., Romero, F., and Alcayaga, H., 2009. Combining the Soil and Water Assessment Tool (SWAT) and MODIS imagery to estimate monthly flows in a data-scarce Chilean Andean basin. Hydrological Sciences Journal, 54 (6), 1053-1067.

Stehr, A., Debels, P., Romero, F., and Alcayaga, H., 2008. Hydrological modelling with SWAT under conditions of limited data availability: evaluation of results from a Chilean case study. Hydrological Sciences Journal, 53 (3), 588-601.

Taye, M.I., Ntegeka, V., Ogiramoi, N.P., and Willems, P., 2011. Assessment of climate change impact on hydrological extremes in two source regions of the Nile River Basin. Hydrology and Earth System Sciences, 15 (1), 209-222.

Taye, M.T., Willems, P., and Block, P., 2015. Implications of climate change on hydrological extremes in the Blue Nile basin: A review. Journal of Hydrology: Regional Studies, 4, 280-293.

Tebebu, T.Y., Steenhuis, T.S., Dagnew, D.C., Guzman, C.D., Bayabil, H.K., Zegeye, A.D., Collick, A.S., Langan, S., MacAlister, C., Langendoen, E.J., Yitaferu, B., and Tilahun, S.A., 2015. Improving efficacy of landscape interventions in the (sub) humid Ethiopian highlands by improved understanding of 
runoff processes. Frontiers in Earth Science, 3.

Tekleab, S., Uhlenbrook, S., Savenije, H.H.G., Mohamed, Y., and Wenninger, J., 2015. Modelling rainfallrunoff processes of the Chemoga and Jedeb meso-scale catchments in the Abay/Upper Blue Nile basin, Ethiopia. Hydrological Sciences Journal, 1-18.

Tibebe, D. and Bewket, W., 2011. Surface runoff and soil erosion estimation using the SWAT model in the Keleta Watershed, Ethiopia. Land Degradation \& Development, 22 (6), 551-564.

Tilahun, S.A., Guzman, C.D., Zegeye, A.D., Engda, T.A., Collick, A.S., Rimmer, A., and Steenhuis, T.S., 2013a. An efficient semi-distributed hillslope erosion model for the subhumid Ethiopian Highlands. Hydrology and Earth System Sciences, 17 (3), 1051-1063.

Tilahun, S.A., Mukundan, R., Demisse, B.A., Engda, T.A., Guzman, C.D., Tarakegn, B.C., Easton, Z.M., Collick, A.S., Zegeye, A.D., Schneiderman, E.M., Parlange, J.-Y., and Steenhuis, T.S., 2013b. A Saturation Excess Erosion Model. Transactions of the ASABE, 56 (2), 681-695.

Weigel, G., 1986. The Soils of the Maybar Area, Wello Research Unit, Ethiopia, University of Bern, Switzerland.

White, K.L. and Chaubey, I., 2005. Sensitivity Analysis, Calibration, and Validations for a Multisite and Multivariable SWAT Model. Journal of the American Water Resources Association, 41 (5), 10771089.

WLRC, 2015. Water and Land Resources Information System (WALRIS) [online]. Available from: http://walris.wlrc-eth.org/ [Accessed 15 Dec 2015].

Zeleke, G., 2000. Landscape Dynamics and Soil Erosion Process Modeling in the North-Western Ethiopian Highlands. African Studies Series A 16. Geographica Bernensia, Bern, Switzerland. 
Table 1 Information on the three small-scale catchments

\begin{tabular}{|c|c|c|c|}
\hline & Andit Tid & Maybar & Anjeni \\
\hline Location of gauging station & $9.815^{\circ} \mathrm{N}, 37.711^{\circ} \mathrm{E}$ & $10.996^{\circ} \mathrm{N}, 39.657^{\circ} \mathrm{E}$ & $10.678^{\circ} \mathrm{N}, 37.5$ \\
\hline Area of hydrological catchment ${ }^{a}$ & 477.3 ha & 112.8 ha & $113.4 \mathrm{~h}$ \\
\hline Area as calculated with SWAT & $474.4 \mathrm{ha}$ & 104.7 ha & $106.56 h$ \\
\hline Altitudinal range $^{\mathrm{a}}$ & $3040-3548 \mathrm{~m}$ asl & $2530-2858 \mathrm{~m}$ asl & 6050 \\
\hline Average slope & $29.4 \%$ & $29.5 \%$ & \\
\hline Rainfall pattern & Bimodal & Bimodal & \\
\hline Growing season $^{a}$ & $175 \mathrm{~d}$ & $175 \mathrm{~d}$ & \\
\hline Major soils $^{\mathrm{a}}$ & $\begin{array}{l}\text { Andosols, Fluvisols, } \\
\text { Regosols, Lithosols }\end{array}$ & $\begin{array}{c}\text { Phaeozems, Lithosols, } \\
\text { Gleysols }\end{array}$ & $\begin{array}{l}\text { Alisols, Nitos } \\
\text { Cambisols }\end{array}$ \\
\hline Average annual min /max temperature ${ }^{b}$ & $8.2^{\circ} \mathrm{C} / 8.6^{\circ} \mathrm{C}$ & $10.9^{\circ} \mathrm{C} / 21$ & $8.6^{\circ} \mathrm{C} / 23.3^{\circ}$ \\
\hline Average annual rainfall ${ }^{\mathrm{b}}$ & $1542 \mathrm{~mm}$ & $1363 \mathrm{mn}$ & $1698 \mathrm{~mm}$ \\
\hline Average annual discharge ${ }^{b}$ & $816 \mathrm{~mm}$ & & $766 \mathrm{~mm}$ \\
\hline Average annual rainfall-runoff ratio ${ }^{c}$ & 0.59 & & 0.46 \\
\hline
\end{tabular}

${ }^{a}=$ SCRP (Bosshart 1997, 1999, Hurni 1998)

$\mathrm{b}=$ WLRC $(2015)$

${ }^{c}=$ Average of years with available precipitation and discharge data 
Table 2 Available weather data and calibration/validation periods

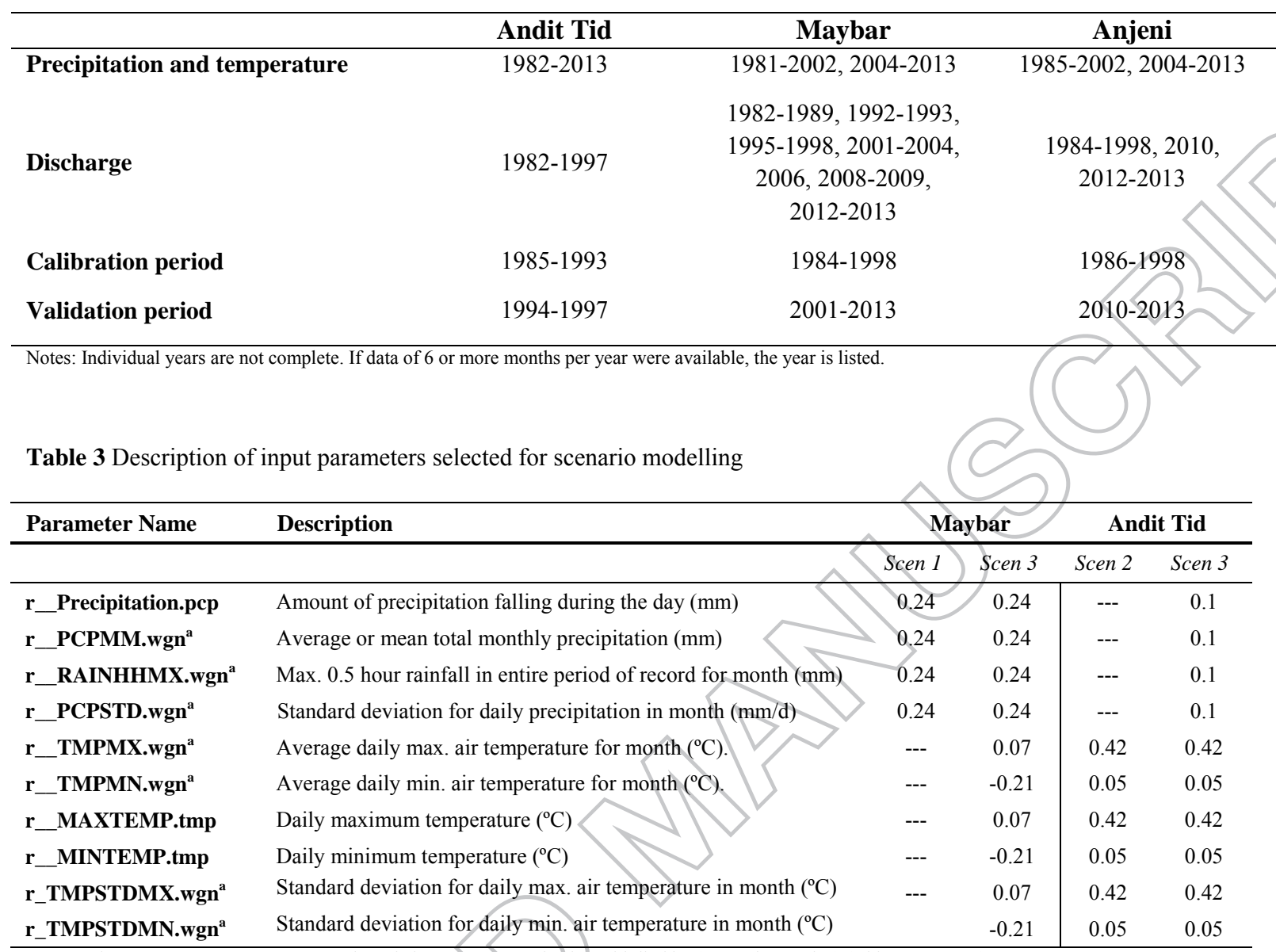

Note: In the parameter names, $\mathrm{r}$ _ means the existing parameter value is multiplied by ( $1+$ a given value) (Abbaspour 2015).

${ }^{a}$ Required for the weather generator (to fill in gaps when measured data is missing). 
Table 4 Description of input parameters selected for calibration, and final parameter ranges after calibration of discharge.

\begin{tabular}{|c|c|c|c|c|c|c|c|}
\hline \multirow[t]{2}{*}{ Parameter Name } & \multirow[t]{2}{*}{ Description } & \multicolumn{2}{|c|}{ Andit Tid } & \multicolumn{2}{|c|}{ Maybar } & \multicolumn{2}{|c|}{ Anjeni } \\
\hline & & Min & $\operatorname{Max}$ & Min & Max & Min & $\operatorname{Max}$ \\
\hline a_CN2.mgt & SCS runoff curve number for moisture condition 2 & $-10^{\mathrm{a}}$ & $10^{\mathrm{a}}$ & -10 & 10 & -10 & 10 \\
\hline v_GW_DELAY.gw & Groundwater delay $(\mathrm{d})$ & 30 & 100 & 50 & 200 & 30 & 150 \\
\hline v_GWQMN.gw & $\begin{array}{l}\text { Threshold depth of water in the shallow aquifer } \\
\text { required for return flow to occur (mm). }\end{array}$ & 50 & 200 & 0 & 200 & 50 & \\
\hline v_ESCO.hru & Soil evaporation compensation factor. & 0.6 & 1 & 0.7 & 1 & & \\
\hline v_GW_REVAP.gW & Groundwater "revap" coefficient & 0.1 & 0.2 & 0.1 & 0.2 & & \\
\hline v_REVAPMN.gw & $\begin{array}{l}\text { Threshold depth of water in the shallow aquifer for } \\
\text { "revap" to occur (mm) }\end{array}$ & 0 & 10 & 0 & & & \\
\hline v_CH_K2.rte & $\begin{array}{l}\text { Effective hydraulic conductivity in main channel } \\
\text { alluvium }\end{array}$ & 0.1 & 130 & 1 & & & 130 \\
\hline v_CH_N2.rt & Manning's " $n$ " value for the main channel & 0 & & 0 & & 0 & 0.3 \\
\hline v__SURLAG.bsn & Surface runoff lag time $(\mathrm{d})$ & 0.05 & & & 0.9 & 0.05 & 1 \\
\hline v_RCHRG_DP.gw & Deep aquifer percolation fraction & 0 & & & 1 & 0 & 1 \\
\hline v_EPCO.hru & Plant uptake compensation factor & & & 0.1 & 0.7 & 0 & 1 \\
\hline r_OV_N.hru & Manning's $n$ value for overland flow & & & -0.2 & 0.1 & -0.1 & 0.2 \\
\hline
\end{tabular}

Table 5 Final calibration and validation statistics for the three small-scale catchments

\begin{tabular}{lcccccccc}
\hline & \multicolumn{2}{c}{ P-factor } & \multicolumn{2}{c}{ R-factor } & \multicolumn{2}{c}{$\mathbf{R}^{2}$} & \multicolumn{2}{c}{ NSE } \\
& Calibration & Validation & Calibration & Validation & Calibration & Validation & Calibration & Validation \\
\hline Andit Tid & 0.84 & 0.79 & 0.58 & 0.79 & 0.83 & 0.73 & 0.8 & 0.68 \\
Maybar & 0.75 & 0.83 & 0.77 & 0.79 & 0.74 & 0.78 & 0.65 & 0.66 \\
Anjeni & 0.81 & 0.81 & 0.85 & 0.77 & 0.93 & 0.89 & 0.93 & 0.88 \\
\hline
\end{tabular}

Table 6 Temperature, precipitation, potential evapotranspiration (PET), and annual rainfall-runoff ratio for scenarios 1-3

\begin{tabular}{|c|c|c|c|c|c|c|c|}
\hline & \multicolumn{3}{|c|}{ Maybar } & \multicolumn{3}{|c|}{ Andit Tid } & \multirow{2}{*}{$\begin{array}{c}\text { Anjeni } \\
\text { Reference }\end{array}$} \\
\hline & Reference $^{a}$ & Scenario 1 & Scenario 3 & Reference $^{a}$ & Scenario 2 & Scenario 3 & \\
\hline Av. annual min temperature $\left({ }^{\circ} \mathrm{C}\right)$ & 10.9 & 10.9 & 8.6 & 8.2 & 8.6 & 8.6 & 8.6 \\
\hline Av. annual max temperature $\left({ }^{\circ} \mathrm{C}\right)$ & 21.7 & 21.7 & 23.3 & 16.4 & 23.3 & 23.3 & 23.3 \\
\hline Av. annual precipitation (mm) & 1363 & 1698 & 1698 & 1542 & 1542 & 1698 & 1698 \\
\hline Av. annual PET $(\mathrm{mm})^{\mathrm{b}}$ & 1330 & 1330 & 1453 & 1099 & 1608 & 1608 & 1505 \\
\hline Av. annual rainfall-runoff ratio & 0.38 & 0.46 & 0.42 & 0.62 & 0.57 & 0.59 & 0.46 \\
\hline
\end{tabular}

${ }^{\mathrm{a}}$ Reference values are measured (temperature and precipitation) or simulated (rainfall-runoff ratio) using the best simulation value from the calibration process.

${ }^{b}$ Potential Evapotranspiration (PET) is calculated using the Hargreaves Method (Hargreaves et al. 1985). 
- Fig. 1 Map overview of the Upper Blue Nile Basin in the Ethiopian Highlands with the WLRC observatories, and the agro-ecological zones according to Hurni (1998)

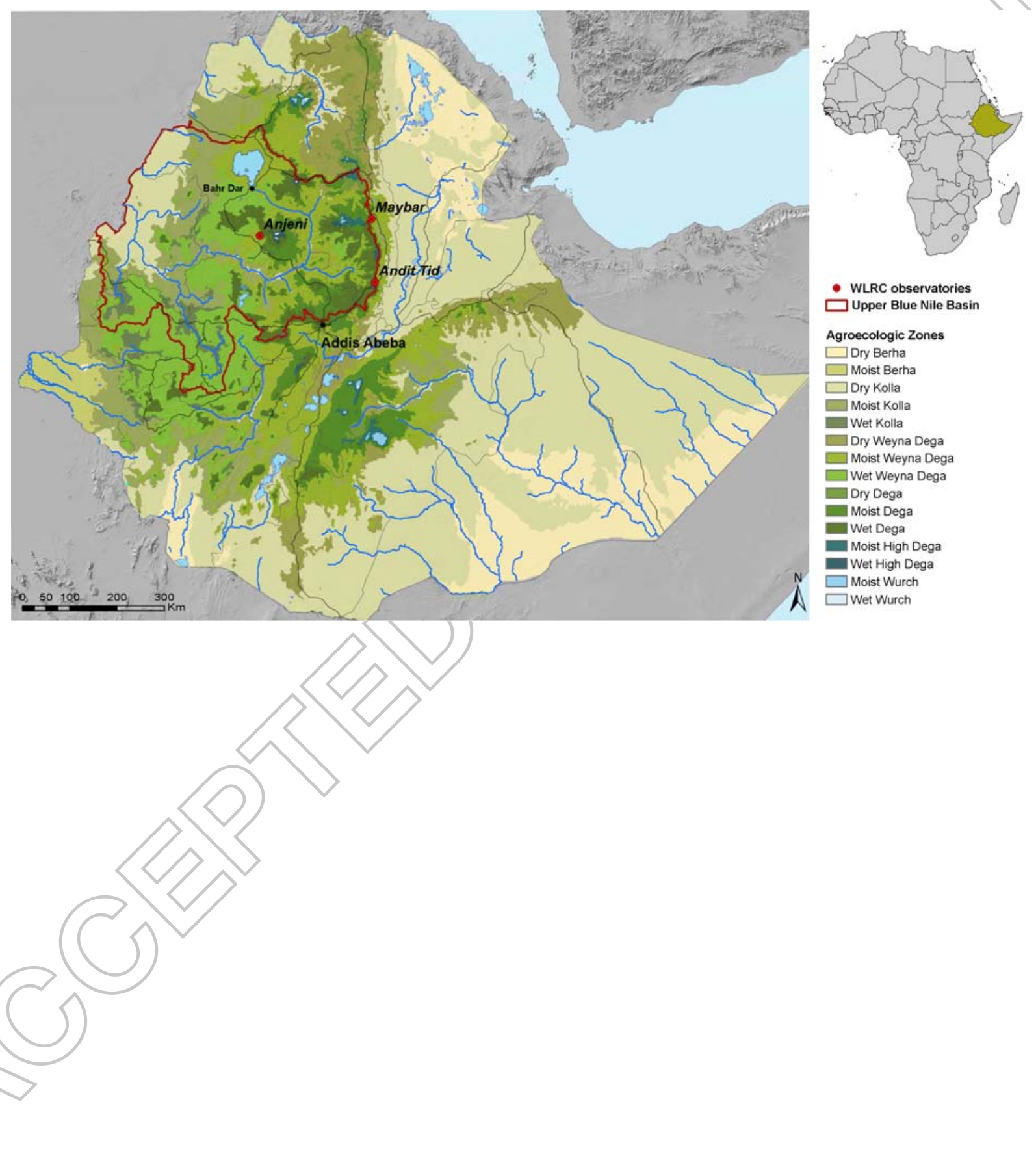


- Fig. 2 Rainfall distribution in Andit Tid, Maybar, and Anjeni (WLRC 2015)
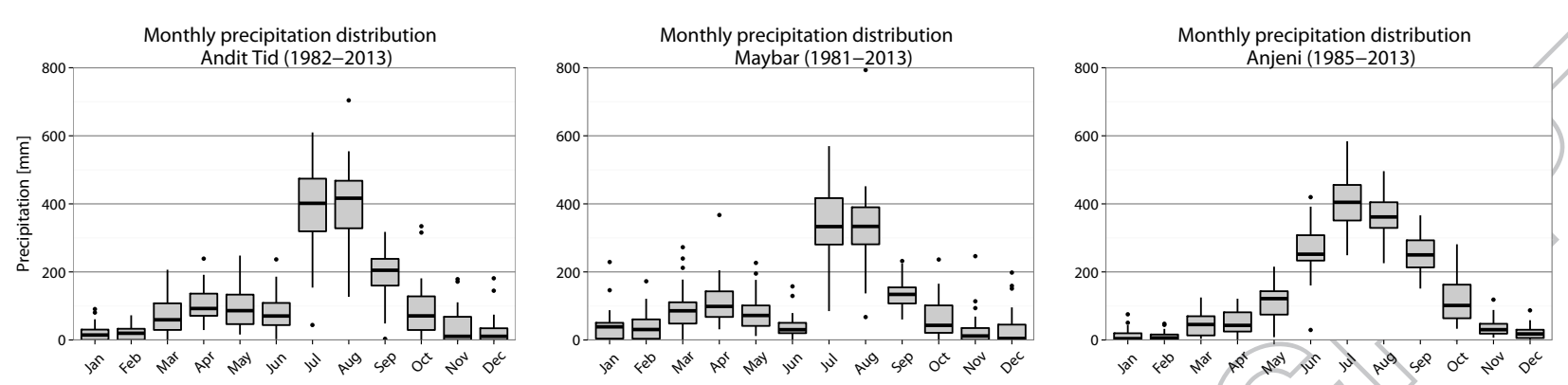

- Fig. 3 Discharge calibration and validation of all three catchments.
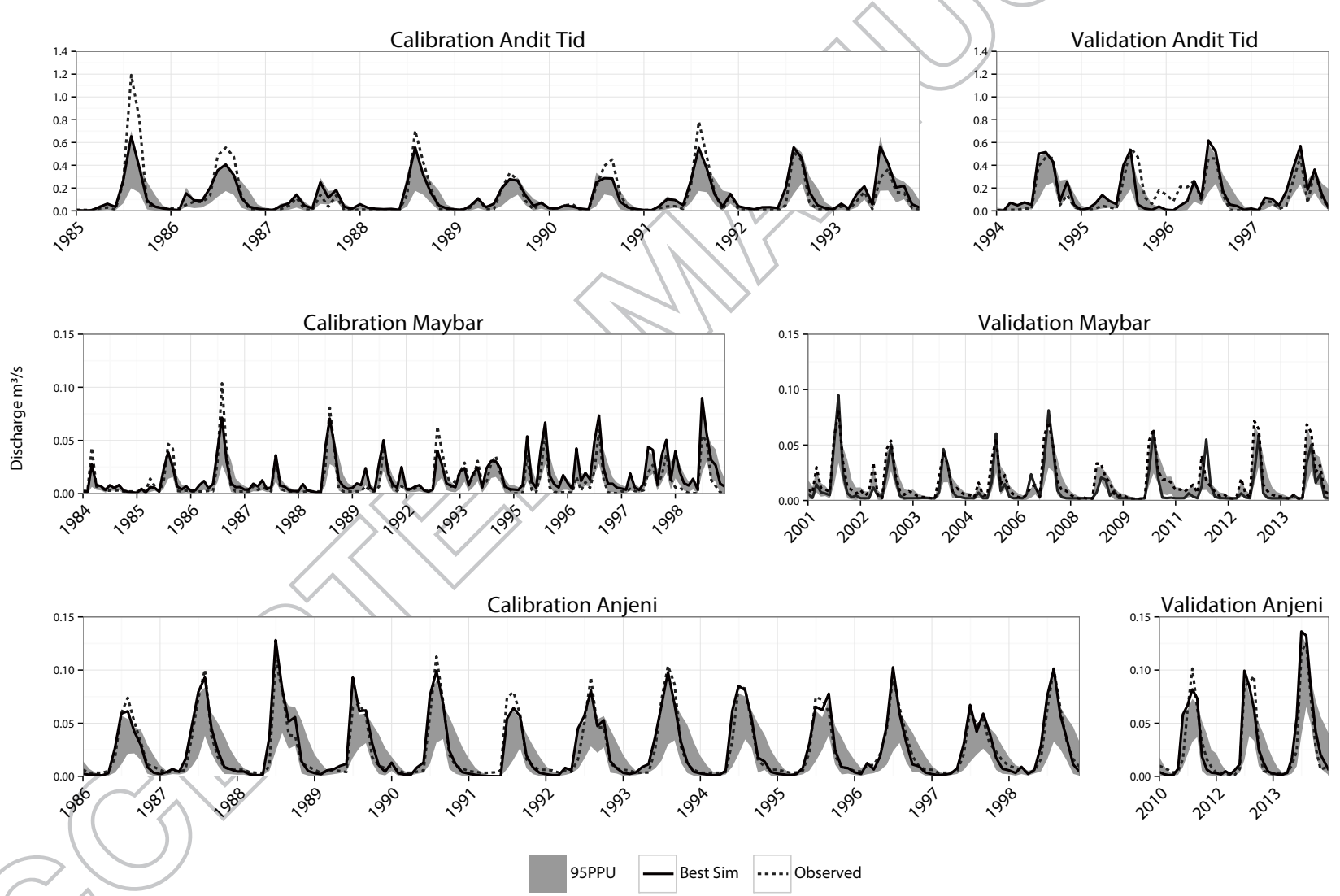
Fig. 4 Average annual and monthly rainfall-runoff ratio with a trend line for all data. Years and months with no measured data have been simulated with the best simulation value from the calibration process (values $>1=1$ ). The SWAT warm-up periods (the first 2 years) have been skipped.
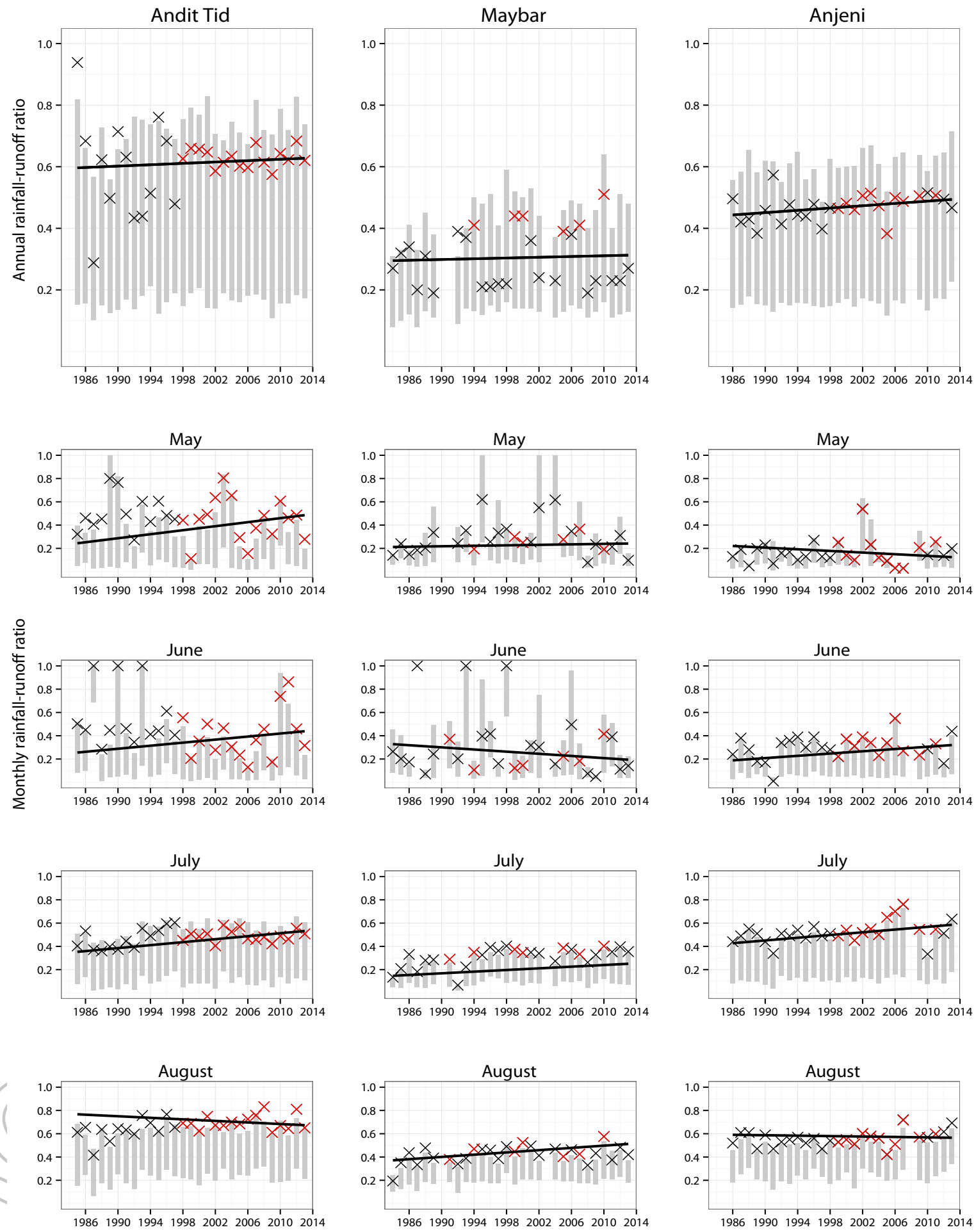

95PPU X measured data $X$ best simulation 
Fig. 5 Scenario 1: Average annual rainfall-runoff ratio over 30 years; expressed with a 95\% prediction uncertainty band (95PPU) and a "best simulation" modelled with measured and adapted (scenario 1) precipitation and temperature values (see Table 6).

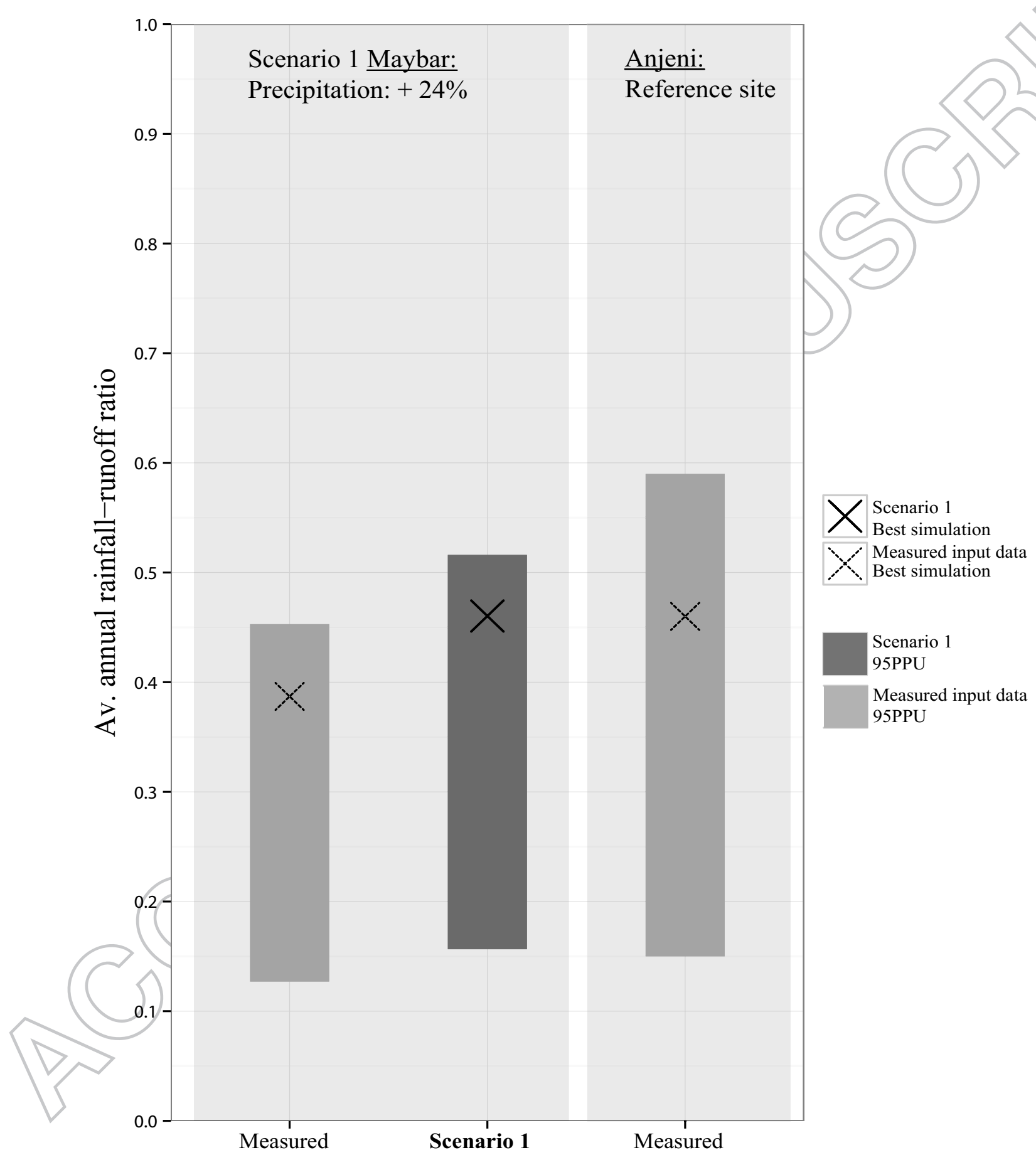


- Fig. 6 Scenario 2: Average annual rainfall-runoff ratio over 30 years; expressed with a 95\% prediction uncertainty band (95PPU) and a "best simulation" modelled with measured and adapted (scenario 2) precipitation and temperature values (see Table 6).

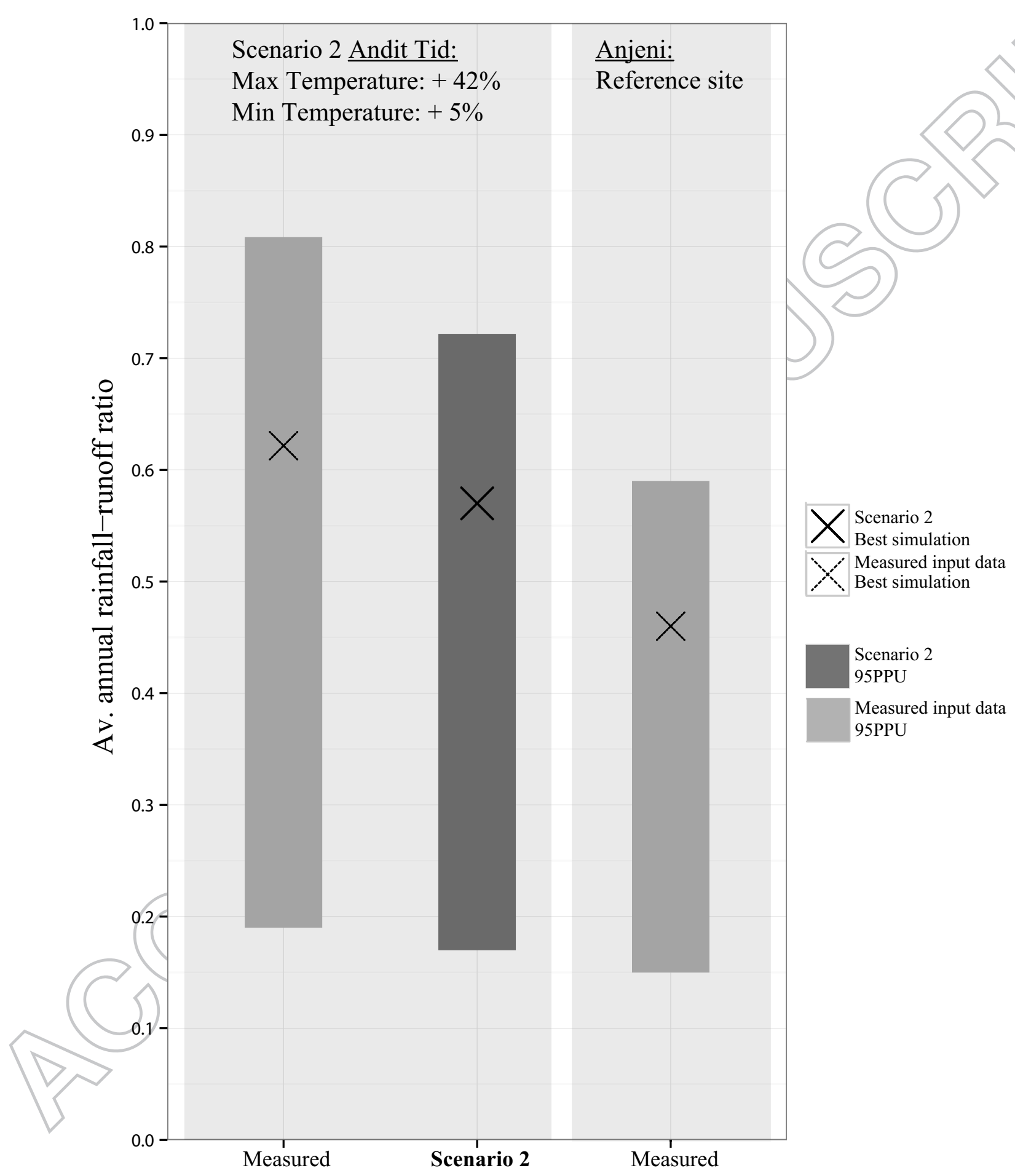


- Fig. 7 Scenario 3: Average annual rainfall-runoff ratio over 30 years; expressed with a $95 \%$ prediction uncertainty band (95PPU) and a "best simulation" modelled with measured and adapted (scenario 3) precipitation and temperature values (see Table 6).

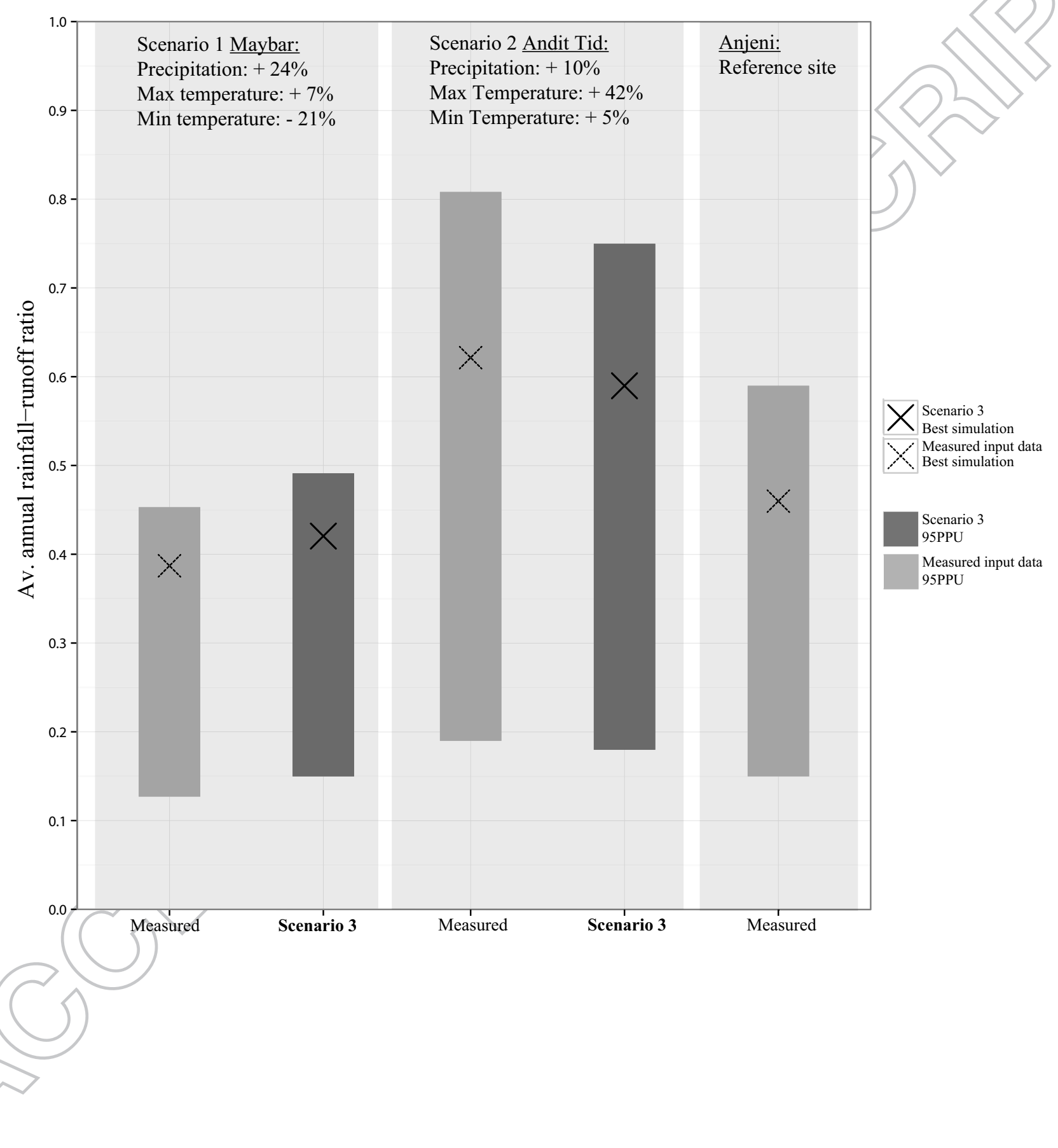

